\title{
ANIMAL WELFARE STANDARDS IN RED DEER (CERVUS ELAPHUS) FARMING
}

\author{
Miroslav I. Urosevic ${ }^{1 *}$, Bruno Esattore ${ }^{2,3}$, Laura Saggiomo ${ }^{4}$, \\ Zoran A. Ristic ${ }^{5}$, Nenad Stojanac ${ }^{6}$ \\ ${ }^{1}$ University of Novi Sad, Faculty of Agriculture, Research and \\ Education Center in Agriculture, Temerin, Serbia. \\ ${ }^{2}$ Institute of Animal Science (VUZV), Department \\ of Ethology, Prague, Czech Republic
}

${ }^{3}$ Czech University of Life Sciences (CZU) Prague, Faculty of Agrobiology, Food and Natural Resources, Department of Animal Husbandry and Ethology, Czech Republic

${ }^{4}$ Czech University of Life Sciences (CZU) Prague, Faculty of Forestry and Wood Sciences, Department of Game Management and Wildlife Biology, Czech Republic

${ }^{5}$ University of Novi Sad, Faculty of sciences, Novi Sad, Serbia

${ }^{6}$ University of Novi Sad, Faculty of agriculture, Veterinary medicine Department, Novi Sad, Serbia

\begin{abstract}
In the last decades, significant interest of consumers in game meat and products has reflected in the worldwide development of wild animal farming. Among the different farmed species, the Red deer (Cervus elaphus) takes an important place, being farmed in several different countries around the world and in most countries within the European Union. In this regard, the European Union has promulgated laws and regulations aimed at defining and organizing this business as well as ensuring the welfare of the animals. So far, relevant data on this topic are not available in Serbia probably due to the lack of deer farms across the country. In this paper, we will review the major issues related to Red deer keeping (i.e., housing, feeding and watering practices, management and handling, transport and velvet harvest) and give the proposals as a basic guideline principles for future Red deer farming in Serbia.
\end{abstract}

Key words: EU legislation, wildlife well-being, farm

${ }^{1 *}$ Corresponding author: miroslav.urosevic@stocarstvo.edu.rs 


\title{
STANDARDI DOBROBITI ŽIVOTINJA NA FARMAMA EVROPSKOG JELENA (CERVUS ELAPHUS)
}

\author{
Miroslav I. Urosević ${ }^{1}$, Bruno Esattore ${ }^{2,3}$, Laura Saggiomo ${ }^{4}$, \\ Zoran A. Ristić ${ }^{5}$, Nenad Stojanac ${ }^{6}$
}

${ }^{1}$ Univerzitet u Novom Sadu, Poljoprivredni fakultet, Istraživački i edukativni centar u poljoprivredi, Temerin, Srbija.

${ }^{2}$ Institut za stočarstvo (VUZV), Departman za Etologiju, Prag, Republika Češka

${ }^{3}$ Češki Univerzitet za prirodne nauke (CZU), Fakultet za agrobiologiju, hranu i prirodne resurse, Departman za stočarstvo i Etologiju, Prag, Republika Češka

${ }^{4}$ Češki Univerzitet za prirodne nauke (CZU), Fakultet šumarstva i nauke o drvetu, Departman za upravljanje divljači i biologiju divljih životinja, Prag, Republika Češka

${ }^{5}$ Univerzitet u Novom Sadu, Prirodnomatematički fakultet, Novi Sad, Srbija

${ }^{6}$ Univerzitet u Novom Sadu, Poljoprivredni fakultet, Departman za veterinarsku medicinu, Novi Sad, Srbija

\section{Kratak sadržaj}

Poslednjih decenija uočava se povećan interes potrošača za meso i proizvode od divljači, što je dovelo do razvoja farmi za uzgoj divljih životinja širom sveta. U odnosu na različite vrste farmskih životinja, Evropski jelen (Cervus elaphus) zauzima značajno mesto, obzirom da se uzgaja na farmama u velikom broju država u svetu i u većini članica Evropske Unije. U tom smislu, Evropska Unija je donela zakone i propise u nameri da definiše i uredi ovaj oblik poslovanja, kao i da osigura dobrobit životinja. Utisak je da u Srbiji nema informacija u odnosu na ovu specifičnu materiju, verovatno i zato što na njenoj teritoriji nema farmi jelena. U ovom radu, mi opisujemo najvažnije teme vezano za gajenje Evropskog jelena (npr. držanje, obezbeđenje hrane i vode, upravljanje i manipulacija sa životinjama, transport i seča rogova) i dajemo predloge kao vodič o osnovnim principima za buduće farme Evropskog jelena u Srbiji.

Ključne reči: EU zakonodavstvo, blagostanje divljih životinja, farme

\section{INTRODUCTION}

\section{The development of deer farming in the world}

The Red deer (Cervus elaphus) population has significantly increased in Europe during the last decades, both in population density and in areas occu- 
pied (Milner et al., 2006). The increasing interest of consumers in the so-called "free-range products" is particularly reflected in the worldwide development of wild animal farming (Piasentier et al., 2005). According to the last reports (Kotrba, 2014), more than 10,000 deer-farming operations exist in several countries of the EU (European Union), counting about 300.000 animals. Apart from the reindeer (Rangifer tarandus), which has been the most widely bred deer species in many Northern countries for the last two thousand years (Clutton-Brock, 1987), the most common species housed in modern deer farms is surely the Red deer (Reinken, 1990; Bartos and Siler, 1993). Although currently there are no registered deer farms in Serbia, it is important to lay the foundation for the future and get prepared for the establishment of this new agricultural option. Thus, it would be useful to design specific animal welfare policies pertaining to the following topics: I) Accommodation and housing II) Provision of feed and water III) Management and handling IV) Transport and V) Velvet harvest. Therefore, we hereby present a scientific investigation and short analysis of the existing legislation in two countries of the European Union, making a summary of the available regulation and research documents concerning the establishment, functioning and management of deer farms.

\section{Accommodation and housing}

Basic technical requirements of a Red deer farm pertain to the minimum size of the pen and stocking density. The criteria regarding the optimal density of animals for enclosed area are defined in the First Animal Keeping Ordinance and shown in Table 1. (Austrian regulation, 2004).

Table 1. Minimum requirements for keeping of Red deer on the farm

\begin{tabular}{|c|c|c|c|}
\hline Species & $\begin{array}{c}\text { Minimum } \\
\text { pen size }\end{array}$ & $\begin{array}{c}\text { Maximum } \\
\text { stocking density }\end{array}$ & $\begin{array}{c}\text { Minimum area of } \\
\text { weather pro- } \\
\text { tection }\end{array}$ \\
\hline Red deer & 2.0 ha & 10 adult animals $/$ ha & $\begin{array}{c}4.0 \mathrm{~m}^{2} / \text { one }^{*} \\
\text { adult animal }^{*}\end{array}$ \\
\hline
\end{tabular}

${ }^{\star}$ Explanation:

1. Two animals up to 18 months of age correspond to one adult;

2. Three animals up to 12 months of age correspond to one adult;

3. Animals from 6 to 12 months of age are equivalent to one adult; 
4. Newborns up to 6 months of age are not to be considered in the stocking density.

These stocking rates are set in order to prevent detrimental effects on production parameters deriving from overcrowded or inadequate farming conditions.

Keeping of male and/or female animals

According to the biology of the species, a breeding group must consist of at least one breeding male (stag) and three breeding females (hinds) (Austrian regulation, 2004). Among the species of Cervids currently existing, the Red deer shows one of the highest levels of sociality (Mattiello and Mazzarone, 2010). Indeed, the young males will aggregate in so called "bachelor groups", whereas the females will keep together with other females and the calves of the year. Older males are rather solitary and join the females only just before the rut, starting to wander again right after (Clutton-Brock et al., 1982). Due to this behavioral peculiarity of the species and where the clinical state of the animals will not require a period of quarantine, it will be consequently necessary to house the animals in groups. It is required to form a unit of at least three individuals to avoid unnecessary stress that may negatively affect the reproductive cycle of the animal, as well as its social and sexual behavior.

\section{Provision of shelter}

Keeping of the deer must be managed in paddocks that can be arranged so that at least $5 \%$ of the surface of the whole pen is covered in shrubs or trees or otherwise shielded. If this is not the case, an additional weather protection must be available. This must be composed of at least two walls and covered with a roof. Its size must be sufficient to provide shelter to all the animals simultaneously (Austrian regulation, 2004). As deer are not well insulated, protection and shelter from climatic extremes should be provided (British regulation, 2006). The provision of sheltered areas is also particularly important during the calving season in paddocks where parturitions occur, as the Red deer is a "hider" species (Putman, 1988).

Design of the fence

Fences are one of the most important features of a deer farm. The fence must be designed to make it impossible for the animals to jump it over or break 
it through. Moreover, it should be designed to prevent the animals from being injured. The contours of the fence must not have corners with acute angles or form a funnel (Austrian regulation, 2004) and its condition, together with the gates', must be checked daily in order to assess potential damages (e.g. fallen trees, willful damage, etc.). Besides preventing the animals from escaping, the role of the fence is to guarantee adequate protection to the stock from predators. Therefore, they need to be of suitable height (minimum 2.5 meters) and well buried into the ground (Austrian regulation, 2004). Barbed wire has to be avoided, as it might cause severe injuries in the case of frightened deer trying to jump out of the fenced area (Kilgour and Dalton, 1984). Electric fences have been successfully used in some cases and they have been recommended by several authors (Kilgour and Dalton, 1984; Reinken, 1990). .

\section{The wallowing}

Another behavioral need that must be satisfied is the "wallowing" (i.e., the action of bathing and rolling in the mud) (Kilgour and Dalton, 1984). It requires the existence of wet depressions in the ground big enough to host more animals at the same time and deep enough to allow the animals to be completely covered in mud up to the withers. Wallowing is believed to have a controlling actions on the ecto-parasites (e.g., ticks and lice), as well as to reduce the body temperature of the animals during particularly hot days. Even if it is included in the behavioral repertoire of both sexes, in the Red deer the stags use wallowing for marking their territory during the rut, urinating in the mud pools before rolling in it in order to enhance their scent (Clutton-Brock et al., 1982).

\section{Feeding and water supply}

Stocking rates must be managed so that every individual will have the chance to forage when grazing on the pasture and consequently maintain an adequate body condition in winter. The facilities for additional food (i.e., hayracks) must be also roofed and raised from the ground level in order to avoid the contamination of the supplies by means of feces and urine. The distance between the boards of the rack should be wide enough to allow the animals to feed comfortably avoiding the risk of being stuck with the head between the planks. Both if the animals feed on pasture or on hay, their diet may be occasionally enriched with potatoes, beets, apples, pears, soy, barley and oats (Dusek et al., 2007) and by salt licks. As regards the water provision, deer must 
have continuous access to a plentiful supply of fresh, clean water. The water troughs must be regularly cleaned and checked as the water must not become stagnant and each water bowl must be systematically checked to ensure that they are functioning correctly (BDFPA, 2016).

\section{Management and handling}

The handling facility

The design of facilities for the capture, handling and manipulation of the animals must be done by keeping in mind the behavior of the species and taking into account the perception that deer have of the surrounding environment and of human beings (Blackshaw, 2003). As the Red deer is a social species (Putman, 1988), isolation is a stressful event for them that could lead to panic (Blackshaw, 2003). Therefore, it is not recommended to confine them alone for long periods, except for quarantine or specific management purposes (Austrian regulation, 2004). A pen book with all the information about the stock (input and output of animals, treatments, findings, deaths, etc.) should also be kept (Austrian regulation, 2004).

Veterinary control in general

The Farm Animal Welfare Committee (British regulation, 2013) marks some handy guidelines regarding the veterinary controls of farmed animals. Medical checks are necessary for all the deer farms. The animals have to be handled (up to 5 times a year) for routine husbandry procedures, as well as for occasional veterinary procedures. The handling can be stressful and physically demanding for the animals, but this factor can be minimized by using well-designed facilities. Veterinaries must also perform an "ante-mortem" inspection in case of deer killing or slaughtering (British regulation, 2013).

\section{Transport}

Transport of live animals

In 2005, the Council Regulation (EC) No 1/2005 (Council Regulation, $2005)$ on the protection of animals during transport and related operations defined the roles and the responsibilities of everybody involved in the transport chain in order to ensure the safety and the wellbeing of the animals. For this 
purpose, the following four mandatory organizational steps have been codified:

i) Control of the conditions of animals and their fitness for travelling.

For all mammals, the following animal categories are considered not eligible for transport: animals that are too young, sick or injured, newborns whose navel is not completely healing, heavily pregnant females and females who have given birth in the previous week before the transportation. According to a specific rule for Cervine species, animals in velvet are not allowed to be transported.

ii) Plan the journey assuring that travelling time is kept to the minimum and the conditions of animals can be periodically checked. For any type of transport, the drivers must hold a relevant certificate of competence, and drivers or handlers need to receive a specific training. There are three different classes of travel: a) Journeys less than 65 kilometers (training without formal qualifications required) b) Journeys over 65 kilometers (relevant certificate of competence required) c) Long travels ( $>8$ hours). In order to receive permits for this class of travel, vehicles inspection and approval are legal requirements. A journey $\log$ is also mandatory.

iii) Ensure that the mean of transport and all the loading and unloading facilities are well designed and in good conditions. The transportation vehicles must be non-slip, easy to clean and disinfect, provide weather protection and sufficient air supply, prevent breakout, and provide to the animals enough space to lie down. The marking of the vehicles or the means of transport must be carried out with a symbol for living animals in an upright position (Austrian Regulation, 2004).

iv) Ensure that the animals can receive food and water every time it is needed, rest is possible and enough space is given. In case of extreme weather conditions, it is necessary to take special measures. In case of particularly hot weather, for example, animals must easily access to shade and water, and have to be regularly inspected. People responsible for the transport should have emergency contingency plans in place for every journey (Council Regulation, 2005).

\section{Velvet harvest}

In many EU countries, the removal of any part of the growing antlers (i.e., before the natural shedding of the velvet) for commercial purposes is forbidden (British regulation, 1980; Austrian regulation, 2014). Antlers removal can be carried out legally only when they are fully calcified and the velvet has been shed (British regulation, 2013). There should be no pain associated with the operation and any accessory cause of stress must be minimized. 


\section{DISCUSSION}

The main welfare issues in deer farming are related to accommodation, housing, management, handling, transport, and velvet harvest (Burton, 1993). As it is inferred from above mentioned examples, some of the countries of the European Union (e.g., Austria and United Kingdom) have a detailed regulation about the deer farming. This refers to the aspects of health, keeping (area, buildings and equipment), protection and welfare of the animals. We expect that the above mentioned list of requirements will meet the needs in Serbia as it had already happened in other European countries (i.e. Austria, United Kingdom) and it will result in proposing the appropriate guidelines for the future Serbian deer farmers. Obviously, it will be necessary to adapt the existing provisions to the Serbian agricultural environment, keeping in mind that deer farms still do not exist in our country. A detailed analysis and feasibility study would represent another important step that has to be taken before the establishment of deer farms in Serbia. After that, it will be necessary to plan a specific strategy for developing of this typology of agribusiness (BDFPA, 2016). Finally, correspondingly with the common practice in many EU countries, it would be very important to establish a regional association of deer farmers as soon as the first farms arise.

\section{CONCLUSION}

According to the BDFPA (2016), deer that have been farmed and are accustomed to human presence (winter housing, regular handling, etc.) behave similarly to cattle and sheep and, with appropriate care and facilities, they can be housed and transported with minimal stress. The low labor regime for deer farming means that it can easily compare to other livestock and arable enterprises.

In this way, the above mentioned regulations could be a good starting point for drafting basic guideline principles for Red deer farming in Serbia. Additionally, considering the lack of information on the topic, it is recommended to perform an extensive scientific research on the status of existing deer parks in Serbia. This project would best be carried out in partnership with a competent institution of the European Union. Moreover, raising awareness about the importance of new regulations and measures for ensuring and monitoring wildlife health should be a prerequisite in the education of all the professional figures involved (deer farmers, technicians, veterinarians, etc.). According to the experiences of the countries of the European Union with 
well-established deer farms (i.e., Austria, United Kingdom, Germany) we can make some estimations in terms of future market trends. Specifically, because of the substantial demand for game meat on the markets in whole Europe, we expect an increase of deer farming production in this part of the world. An additional benefit of deer farming is the production of trophies, highly valuable and particularly requested by Chinese companies.

\section{ACKNOWLEDGEMENT}

The authors would like to address a special thanks to Vratislav Kšáda and Petr Janovsky from the Institute of Animal Science of Prague for the informal consultation about deer housing. The present work is part of the research done within the scientific projects „TR-31084“ and „III-46005“ granted by the Serbian Ministry of Education, Science and Technological Development, and has been also supported by the Ministry of Agriculture of the Czech Republic (MZE-RO0718).

\section{REFERENCES}

1. Austrian regulation: Federal Act on the Protection of Animals (Animal Protection Act - TSchG) Federal Law Gazette I No. 118/2004. https://www.ris. bka.gv.at/Dokumente/Erv/ERV_2004_1_118/ERV_2004_1_118.pdf

2. BDFPA (British Deer Farms \& Parks Association): Deer farming - a background, 2016 www.bdfpa.org/deerfarming/ap87Wtqmqxm.pdf

3. Bartos L., Siler J.: Survey of game farming in Europe. Roma, FAO, 1993.

4. Burton B.: Welfare of farmed fallow deer - a Canadian's perspective. In: G.W. Asher, Editor, Proceeding of first World Forum on Fallow Deer Farming, Mudgee, 10-13. March, Australia, 1993, 209-224

5. Blackshaw J.K.: Notes on some topics in applied animal behaviour. Brisbane, School of Veterinary Science, University of Queensland, 2003. http:// www.animalbehaviour.net

6. British regulation: Welfare of Livestock (Deer) Order, Animals prevention of cruelty. Statutory instruments, 593, 1980. http://www.legislation.gov.uk/ uksi/1980/593/pdfs/uksi_19800593_en.pdf

7. British regulation: "DEFRA" (Department for Environment, Food \& Rural Affairs - Government of United Kingdom), Animal Welfare: Codes of recommendations for the welfare of livestock - Deer, 2006. http://adlib. everysite.co.uk/adlib/defra/content.aspx?id=000IL3890W.180GWU36OD ML0O 
8. British regulation: FAWC (Farm Animals Welfare Committee), Opinion on the welfare on farmed and park deer, 2013. https://assets.publishing.service. gov.uk/government/uploads/system/uploads/attachment_data/file/324515/ FAWC_opinion_on_the_welfare_of_farmed_and_park_deer.pdf

9. Council Regulation (EC) No 1/2005 of 22 December 2004 on the protection of animals during transport and related operations and amending Directives 64/432/EEC and 93/119/EC and Regulation (EC) No1255/97 https:// eur-lex.europa.eu/legal-content/EN/TXT/?uri=celex\%3A32005R0001

10. Clutton-Brock J.: A natural history of domesticated mammals. Cambridge, Cambridge University Press, 1987.

11. Clutton-Brock T.H., Guinness F.E., Albon S.D.: Red deer: behavior and ecology of two sexes. Chicago, University of Chicago press, 1982.

12. Dusek A., L. Bartos L., Losos S.: Response of antler growth to changing rank of fallow deer buck during the velvet period. Canadian Journal of Zoology, 75, 1934-1939, 2007.

13. Kilgour R., Dalton C.: Livestock behaviour. A practical guide. Bungay, (UK), Granada Publishing Limited, 1984.

14. Kotrba R.: The Federation of European Deer Farmers Associations (FEDFA) unites and represents European deer farmers and by encouraging them to pull together creates an effective force. In: Berzins A., Editor, Proceeding, The international Scientific Conference on Deer Genetics and Management. August 6-7., Sigulda, (Latvia), 2014, 22-24

15. Mattiello S., Mazzarone V.: Il cervo in Italia. Biologia e gestione tra Alpi e Appennini. Italy, Geographica, 2010.

16. Milner J.M., Bonenfant C., Mysterud, A., Gaillard J.M., Csanyi S., Stenseth N.C.: Temporal and Spatial Development of Red Deer Harvesting in Europe: Biological and Cultural Factors. Journal of Applied Ecology, 43, 721-734, 2006.

17. Piasentier E., Bovolenta S., Viliani M.: Wild Ungulate Farming Systems and Product Quality. Veterinary Research Communications 29, 65-70, 2005.

18. Putman R.J.: The natural history of deer. New York, Comstock Publishing Associates. Cornell University Press, 1988.

19. Reinken G.: Deer Farming: a practical guide to German Techniques. Ipswich, (UK), Farming Press, 1990.

Primljeno: 16.10 .2018 .

Odobreno: 28.12.2018. 